\title{
Regulation of the $\mathrm{LPA}_{2}$ Receptor Signaling through the Carboxyl- Terminal Tail-Mediated Protein-Protein Interactions
}

\author{
Fang-Tsyr Lin ${ }^{*}$ and Yun-Ju Lai \\ Department of Cell Biology University of Alabama at Birmingham Birmingham, AL 35294-0005
}

\begin{abstract}
While it is well known that lysophosphatidic acid (LPA) mediates diverse physiological and pathophysiological responses through the activation of G protein-coupled LPA receptors, the specificity and molecular mechanisms by which different LPA receptors mediate these biological responses remain largely unknown. Recent identification of several PDZ proteins and zinc finger proteins that interact with the carboxyl-terminal tail of the $\mathrm{LPA}_{2}$ receptor provides a considerable progress towards the understanding of the mechanisms how the $\mathrm{LPA}_{2}$ receptor specifically mediates LPA signaling pathways. These findings have led to the proposal that there are at least two distinct protein interaction motifs present in the carboxyl terminus of the $\mathrm{LPA}_{2}$ receptor. Together, these data provide a new concept that the efficiency and specificity of the $\mathrm{LPA}_{2}$ receptor-mediated signal transduction can be achieved through the cross-regulation between the classical $\mathrm{G}$ protein-activated signaling cascades and the interacting partner-mediated signaling pathways.
\end{abstract}

\section{Keywords}

LPA; $\mathrm{LPA}_{2}$ receptor; PDZ; LIM; zinc finger; protein-protein interactions

\section{Introduction}

LPA is a growth factor-like phospholipid, which mediates diverse biological responses such as cell proliferation, differentiation, migration, survival, angiogenesis, inflammation and platelet aggregation [1-5]. In the past decade, the identification of at least seven $G$ proteincoupled LPA receptors, including $\mathrm{LPA}_{1} / \mathrm{EDG} 2, \mathrm{LPA}_{2} / \mathrm{EDG} 4$ and $\mathrm{LPA}_{3} / \mathrm{EDG} 7$ of the Endothelial Differentiation Gene (EDG) family and the structurally distinct LPA $4 / \mathrm{P} 2 \mathrm{Y} 9 /$ GPR23, $\mathrm{LPA}_{5} / \mathrm{GPR} 92$, GPR87, and P2Y5 of the P2Y purinoreceptor family has provided a big step toward the understanding of LPA actions [6-12]. These LPA-bound membrane receptors couple to $G_{\mathrm{s}}, G_{\mathrm{i} /}, \mathrm{G}_{\mathrm{q}}$ and/or $\mathrm{G}_{12 / 13}$ proteins to activate various signaling pathways. In addition, LPA can bind to the nuclear peroxisome proliferator-activated receptor $\gamma$ (PPAR $\gamma$ ) to regulate vascular remodeling [13,14]. Along with the rapid development of this field, more efforts have been made to determine the specificity and mechanisms by which different LPA receptors mediate LPA actions. Among all of the LPA receptors, the $\mathrm{LPA}_{2}$ receptor is unique in the carboxyl-terminal tail, in which it contains two distinct protein-protein interaction domains to bind several PDZ proteins and zinc finger proteins, respectively [15-21]. These protein-protein interactions confer the specificity, efficiency and diversity by which the $\mathrm{LPA}_{2}$ receptor mediates LPA-evoked signal transduction, which will be the focus of this review.

\footnotetext{
*To whom correspondence should be addressed. Mailing address: MCLM 360A, 1918 University Blvd., Birmingham, AL 35294-0005, TEL: 205-975-5060, FAX: 205-975-5648. E-mail: flin@uab.edu
} 


\section{Functional roles of the $\mathrm{LPA}_{2}$ receptor}

In response to LPA stimulation, the $\mathrm{LPA}_{2}$ receptor couples to $\mathrm{G}_{\mathrm{i} / \mathrm{o}}, \mathrm{G}_{\mathrm{q}}$ and $\mathrm{G}_{12 / 13}$ proteins to mediate cellular responses such as DNA synthesis, MAP kinase activation, AKT activation, inhibition of adenylyl cyclase, increase of inositol phosphates and intracellular calcium concentration, cell rounding, cell adhesion and cell migration [8]. These signaling events are partially impaired in mouse embryonic fibroblasts (MEFs) derived from the $\mathrm{LPA}_{2}{ }^{-/}$mice, and are dramatically reduced or completely abolished in MEFs derived from the $L P A_{1}{ }^{-1-}$, $L P A_{2}{ }^{-/-}$mice, suggesting a functional redundancy of $\mathrm{LPA}_{1}$ and $\mathrm{LPA}_{2}$ receptors in some of the signaling pathways. However, disruption of the $\mathrm{LPA}_{2}$ receptor gene does not result in any developmental abnormality [22].

Although the $\mathrm{LPA}_{2}$ receptor is not required for growth and development, increasing evidence has implicated LPA and the $\mathrm{LPA}_{2}$ receptor as the key mediators in cancer progression. It has been reported that the expression of the $\mathrm{LPA}_{2}$ receptor is up-regulated in ovarian cancers, invasive ductal carcinoma tissue of breast cancers, colorectal cancers and thyroid cancers [23-26]. Recently autotaxin/lysophospholipase D (ATX/lysoPLD) has been known to mediate tumor invasion, neovascularization and metastasis through the production of LPA in the cellular microenvironment [5,27]. And the platelet-derived LPA has been shown to act as a tumor cell mitogen and promoting factor of osteolysis during bone metastasis [28]. Although several actions of LPA can contribute to tumorigenesis, including cell migration, cell proliferation, cell survival and transcriptional activation of genes involved in these signaling events [5], it remains unclear whether the $\mathrm{LPA}_{2}$ receptor meditates these actions through specific signaling pathways.

\section{Regulation of $\mathrm{LPA}_{2}$ receptor functions through the carboxyl-terminal tail- mediated protein-protein interactions}

The classical paradigm of $\mathrm{G}$ protein-coupled receptor activation involves the coupling of ligand-bound receptors to heterotrimeric $\mathrm{G}$ proteins, which sequentially activates the downstream effector molecules and induces cellular responses. However, emerging evidence has revealed that other mechanisms can cross-regulate GPCR signaling pathways. For example, a number of GPCRs can interact with cellular proteins through the intracellular loops or carboxyl-terminal tail. These interacting partners participate in the regulation of receptor trafficking, dimerization, effector coupling, membrane expression and subcellular localization, etc., thereby determining the signal specificity and efficiency $[29,30]$.

The $\mathrm{LPA}_{1}, \mathrm{LPA}_{2}$ and $\mathrm{LPA}_{3}$ receptors share a high homology in the sequences except for the carboxyl-terminal tail, suggesting that this region may specifically regulate the unique functions of each receptor. The structure of $\mathrm{LPA}_{2}$-CT (a.a. 296-351) contains a di-leucine motif and several putative palmitoylated cysteine residues in the proximal region, and a class I PDZbinding motif at the distal end. It also contains several serine and threonine residues presumably can be phosphorylated by G protein-coupled receptor kinases (GRKs), which are important for $\beta$-arrestin binding and receptor internalization. The last four amino acids, DSTL, known as a class I PDZ-binding motif, mediates the interactions with NHERF2 $\left(\mathrm{Na}^{+} / \mathrm{H}^{+}\right.$exchanger regulatory factor 2), PDZ-RhoGEF, LARG (Leukemia-associated RhoGEF) and MAGI-3 (membrane-associated guanylate kinase with an inverted domain structure-3) [16-18,20,21], whereas the proximal region is responsible for the association with several zinc finger proteins, including the LIM domain-containing TRIP6 (thyroid hormone receptor-interacting protein 6) and the proapoptotic Siva-1 protein [15,19] (Table 1). Except for PDZ-RhoGEF and LARG that can bind to both $\mathrm{LPA}_{1}$ and $\mathrm{LPA}_{2}$ receptors [18], other proteins selectively interact with the $\mathrm{LPA}_{2}$ receptor but not other LPA receptors, suggesting that these interacting partners may play specific roles in regulating $\mathrm{LPA}_{2}$ receptor functions. 


\subsection{PDZ-mediated protein-protein interactions}

PDZ domains, derived from the initials of three proteins containing such domains including PSD-95, the Drosophila discs-large tumor suppressor protein $\underline{D} \lg \mathrm{A}$ and the tight junction protein $\mathrm{ZO}-1$, are composed of $\sim 90$ amino acids that function as the protein interaction modules, which bind to the specific short peptide motif found in the carboxyl-terminus or internal region of a variety of target proteins [31-35]. Most of the PDZ domains are involved in the organization of multi-protein complexes, which allows the stable localization of interacting proteins to achieve the efficiency and fidelity of the signal transduction. The PDZbinding motifs can be classified into three groups, which are composed of the four amino acids, $\mathrm{X}-\mathrm{S} / \mathrm{T}-\mathrm{X}-\mathrm{L} / \mathrm{V}$ (class I), X- $\phi-\mathrm{X}-\phi$ (class II) and X-D-X-V (class III), respectively $(\phi$, hydrophobic amino acid; $X$, unspecified amino acid) [36]. These PDZ-binding motifs can be found in the carboxyl-terminus of several LPA receptors, such as $\mathrm{LPA}_{1}(\mathrm{HSVV}), \mathrm{LPA}_{2}(\mathrm{DSTL})$ and $\mathrm{LPA}_{5}(\mathrm{DSAL})$.

Interestingly, the first reported $\mathrm{LPA}_{2} \mathrm{cDNA}$ clone was derived from an ovarian tumor library, which lacks the last four amino acids (DSTL), but is 31 amino acids longer than the reported human cDNA sequences [8]. This can be explained by one guanine base deletion at the 3 ' end of the coding sequences, which leads to a frame-shift mutation in the carboxyl-terminal region of the protein. However, whether these mutations lead to any de-regulation of $\mathrm{LPA}_{2}$ in tumor development is not known.

\subsubsection{NHERF2 regulates LPA-mediated phospholipase C- $\beta$ signaling pathway} and the activation of ERKs and $A K T-T h e \mathrm{Na}^{+} / \mathrm{H}^{+}$exchanger regulatory factors NHERF1 (also known as EBP50) and NHERF2 (also known as E3KARP) possess two tandem PDZ domains and a carboxyl-terminal domain that binds to the actin-binding proteins ezrin, radixin, moesin and merlin $[37,38]$. The NHERF family members function as scaffold proteins by associating with a number of transporter, ion channels, transcription factors, different signaling molecules and growth factor receptors [38-40]. Emerging data also show that the two PDZ domains of NHERF1 and NHERF2 can interact with the carboxyl-terminal PDZ-binding motifs of a number of $\mathrm{G}$ protein-coupled receptors, and regulate receptor trafficking, localization and/or other functions [41]. However, NHERF1 and NHERF2 seem to have a distinct peptide-binding specificity. For example, PDZ1 of NHERF1 binds to the $\beta_{2}$-adrenergic receptor (DSLL), P2Y1 purinergic receptor (DTSL), and cystic fibrosis transmembrane regulator (CFTR)(DTRL) [42,43]. But NHERF1 does not bind to the $\mathrm{LPA}_{1}$ receptor (HSVV) or $\mathrm{LPA}_{2}$ receptor (DSTL) [17]. Likewise, PDZ1 of NHERF2 binds to the $\beta_{2 \text {-adrernergic }}$ receptor (DSLL) [42]; however, PDZ2 of NHERF2 specifically binds to the $\mathrm{LPA}_{2}$ receptor (DSTL) but not $\mathrm{LPA}_{1}$ receptor (HSVV) [17]. These observations suggest that although the last four amino acid residues of the target receptors are required for PDZ domain recognition, other adjacent residues are also involved in determining the specificity and/or affinity of the interaction.

Through the interaction with the $\mathrm{LPA}_{2}$ receptor, NHERF2 potentiates LPA-induced ERK activation and COX-2 induction [17]. This effect can be partly attributed to the specific coupling of the $\mathrm{LPA}_{2}$ receptor to phospholipase C- $\beta 3$ (PLC- $\beta 3$ ) by NHERF2, which regulates inositol phosphoate production, calcium mobilization and protein kinase $\mathrm{C}$ activation. Intriguingly, both PLC- $\beta 3$ and the $\mathrm{LPA}_{2}$ receptor bind to the same PDZ domain of NHERF2. Since NHERF proteins can form oligomers through PDZ domains [44,45], NHERF2 must be self-associated to form a multi-protein complex containing the $\mathrm{LPA}_{2}$ receptor and PLC- $\beta 3$. In addition, it has been reported that LPA-induced activation of ERKs and AKT is attenuated by the inhibition of NHERF2 expression in Caco- 2 colon cancer cells that predominantly express the $\mathrm{LPA}_{2}$ receptor but not $\mathrm{LPA}_{1}$ or $\mathrm{LPA}_{3}$ receptor [21]. 
3.1.2. NHERF2 links the $\mathrm{LPA}_{2}$ receptor with CFTR-Cystic fibrosis transmembrane conductance regulator (CFTR) is a cAMP-regulated chloride channel, which plays a critical role in cholera toxin-induced secretory diarrhea [46]. Through the PDZ domain-mediated interactions, NHERF2 bridges the $\mathrm{LPA}_{2}$ receptor and CFTR, and facilitates the macromolecular complex formation at the apical plasma membrane of intestinal epithelial cells [20]. When activated by LPA, the $\mathrm{LPA}_{2}$ receptor couples to $\mathrm{G}_{\mathrm{i}}$ proteins to reduce cAMP levels, thereby inhibiting PKA-mediated activation of CFTR and cholera toxin-induced secretory diarrhea [20]. These studies demonstrate that the triple complex formation among the $\mathrm{LPA}_{2}$ receptor, NHERF2 and CFTR plays a key role in LPA-mediated inhibition of CFTR activity.

\subsubsection{PDZ domain-containing Rho GEFs and MAGI-3 regulate $\mathrm{LPA}_{\mathbf{2}}$ functions in} RhoA and ERK activation-In line with the discovery of NHERF2 as an $\mathrm{LPA}_{2}$ receptorinteracting protein, two reports have demonstrated that the PDZ-binding motif of $\mathrm{LPA}_{2}$ receptor can also interact with the PDZ domains of two RhoA-specific guanine nucleotide exchange factors (GEFs) and the MAGI family members [16,18]. The activated LPA receptors couple to $\mathrm{G}_{12 / 13}$ proteins, which can activate RhoA signaling through the recruitment of the RGS domain-containing Rho GEFs, including PDZ-RhoGEF, LARG and p115-RhoGEF [47-50]. Among these Rho GEFs, the PDZ domain-containing PDZ-RhoGEF and LARG are capable of binding to the $\mathrm{LPA}_{1}$ and $\mathrm{LPA}_{2}$ receptors, and regulate LPA-induced RhoA activation [18]. These findings suggest that the PDZ-mediated interaction may facilitate the recruitment of PDZ domain-containing RhoGEFs to the proximity of $\mathrm{G}_{12 / 13}$ proteins, thereby enhancing their ability to catalyze the guanine nucleotide exchange of RhoA.

Using a PDZ proteomic array to screen the proteins that interact with the $\mathrm{LPA}_{2}$ receptor, several PDZ domain-containing proteins have been identified, which include NHERF1 (PDZ1), NHERF2 (PDZ2), neurabin, MAGI-2 (PDZ5) and MAGI-3 (PDZ5) [16]. However, PDZRhoGEF and LARG were not found by this assay, suggesting a differential in vitro binding affinity among these PDZ-mediated interactions. MAGI proteins contain multiple PDZ domains, WW domains and a guanylate kinase-like domain, allowing them to function as scaffold proteins to enable multi-protein complex formation [51]. These proteins are present at the areas of cell-cell contact such as the synaptic junctions in neurons and the tight junctions in epithelial cells [51]. MAGI-3 can interact with PTEN, receptor tyrosine phosphatase- $\beta$, transforming growth factor- $\alpha$ (TGF- $\alpha$ ), frizzled receptor and the $\beta_{1}$-adrenergic receptor [52-56]. It has been reported that MAGI-3 can interact with PTEN to negatively modulate AKT activity, and bind to the $\beta_{1}$-adrenergic receptor to impair $\mathrm{G}_{\mathrm{i}}$-mediated AKT activation [52, 55]. However, overexpression of MAGI-3 or inhibition of MAGI-3 expression does not significantly affect LPA-induced AKT activation [16]. Instead, the interaction of MAGI-3 with the $\mathrm{LPA}_{2}$ receptor regulates LPA-induced activation of RhoA and ERKs [16]. Overexpression of MAGI-3 enhances LPA-induced RhoA activation but has little effect on ERK activation, whereas knockdown of MAGI-3 inhibits LPA-induced RhoA and ERK activation. Together, these data demonstrate that the $\mathrm{LPA}_{2}$ receptor functions can be differentially regulated through PDZ-mediated protein-protein interactions in different cellular contexts.

\subsection{Zinc finger-mediated protein-protein interactions}

Using the carboxyl-terminal tail of the $\mathrm{LPA}_{2}$ receptor as bait in a yeast two-hybrid screen, two zinc finger-containing molecules have been identified, including TRIP6 and Siva-1 [15,19]. The structure of TRIP6 contains an N-terminal proline-rich domain, three carboxyl LIM domains and a PDZ-binding motif at the carboxyl-terminal end. The LIM domains (named by the initials of Lin-11, Isl-1, and Mec-3) contain two zinc finger motifs, which are critical for protein-protein interactions [57]. TRIP6 binds to the LPA 2 receptor mainly through LIM2-3 domains; however, LIM1 can facilitate this interaction [15]. The structure of Siva-1 protein contains an internal death domain homology region (DDHR) and two carboxyl zinc finger 
motifs; however, lacking histidine residues [58]. The association with the $\mathrm{LPA}_{2}$ receptor is mediated by the carboxyl-terminal zinc finger motif of Siva-1, which resembles the second half of TRIP6-LIM3 domain [19]. Indeed, the domain mapping shows that these two proteins bind to the same motif located in the proximal region of the carboxyl-terminal tail of the $\mathrm{LPA}_{2}$ receptor (F.-T. Lin and G. Tigyi, unpublished). However, there are some differences in their interactions. TRIP6 associates with the membrane-bound $\mathrm{LPA}_{2}$ receptor in an LPAdependent manner, whereas Siva-1 binds to the $\mathrm{LPA}_{2}$ receptor on the membrane or in the cytosol in the absence or presence of LPA $[15,19]$. The interaction of TRIP6 with the LPA 2 receptor is transient since LPA treatment for 15-20 min induces the translocation of TRIP6 to focal adhesion plaques where the $\mathrm{LPA}_{2}$ receptor is not present. In contrast, Siva-1 seems to preferentially bind to the internalized $\mathrm{LPA}_{2}$ receptor.

\subsubsection{The LIM domain-containing TRIP6 regulates $L P A_{2}$ receptor-mediated cell} migration-TRIP6, also known as ZRP-1 (Zyxin-related Protein 1), is a focal adhesion molecule known to regulate cell motility and transcriptional control [15,59-62]. Together with LPP, zyxin, and more distantly with ajuba and LIMD1, these proteins form the zyxin family members [59]. Through the LIM domain-mediated protein-protein interactions, these molecules function as scaffold or adaptor proteins for the assembly of multi-protein complexes involved in actin rearrangement, cell adhesion and motility [63]. LPA stimulation promotes the recruitment of TRIP6 to the activated $\mathrm{LPA}_{2}$ receptor, and induces the association of TRIP6 with the components of focal complexes, including paxillin, p130 cas, FAK and c-Src [15]. Subsequently, TRIP6 is phosphorylated by c-Src at Tyr-55, a unique site only present in TRIP6 but not other zyxin family members [64]. This phosphorylation transforms the $\mathrm{pY}^{55}$-Q-A-P motif of TRIP6 into a docking site for Crk SH2 domain, thereby enhancing LPA-induced morphological changes and cell migration. In addition, knockdown of TRIP6 attenuates LPAinduced, c-Src-mediated ERK activation. In contrast to c-Src, the PTPL1/FAP-1 (Fasassociated phosphatasae-1) tyrosine phosphatase binds to the carboxyl-terminal PDZ-binding motif and LIM3 of TRIP6 [65]. Dephosphorylation of TRIP6 by PTPL1/FAP-1 serves as a molecular switch by inhibiting TRIP6 binding to Crk, thereby negatively regulating TRIP6 function in LPA-induced adhesion turnover and cell migration [66]. Given the high sequence homology among the LIM domains of TRIP6, LPP and zyxin, LPP and zyxin are also found to bind to the $\mathrm{LPA}_{2}$ receptor in an LPA-dependent manner.

\subsubsection{The interaction of the $\mathrm{LPA}_{2}$ receptor with Siva-1 promotes LPA-mediated} down-regulation of Siva-1_LPA is known as a promoting factor for cell survival [67]. Several pro-survival signaling pathways have been defined for this protective effect, including the activation of AKT/PKB, ERKs and NF- $\mathrm{KB}[68,69]$. Among different LPA receptors, the $\mathrm{LPA}_{1}$ and $\mathrm{LPA}_{2}$ receptors have been shown to mediate these effects [70-72]. In contrast to the $\mathrm{LPA}_{2}$ receptor, Siva-1 functions as a proapoptotic protein, which is transcriptionally activated by p53 and E2F1 during DNA damage response [73]. Although the mechanism how Siva-1 regulates apoptosis is not fully understood, it has been reported hat Siva-1 promotes apoptosis through a caspase-3-dependent mitochondrial pathway [74], and can function as a negative regulator of NF- $\mathrm{KB}$ in T cell receptor-mediated activation-induced cell death [75]. In addition, Siva-1 binds to Bcl-xL and inhibits Bcl-xL-mediated protection against UV radiation-induced apoptosis [76].

Several G protein-coupled receptors have been shown to undergo ligand-stimulated ubiquitination and degradation through proteasomal or lysosomal pathways [77]. It has been noted that prolonged LPA stimulation not only down-regulates the $\mathrm{LPA}_{2}$ receptor but also concomitantly targets the $\mathrm{LPA}_{2}$ receptor-interacting Siva- 1 for ubiquitination and proteasomal degradation [19]. As a result, the proapoptotic activity of Siva-1 during DNA damage response is attenuated by LPA. Thus, in addition to activating AKT/PKB and ERK pathways to promote 
cell survival, LPA can directly inhibit the proapoptotic function of Siva-1 through the specific binding of Siva-1 to the $\mathrm{LPA}_{2}$ receptor.

\section{Concluding remarks}

As different LPA receptors may couple to the same $\mathrm{G}$ proteins to activate the downstream cascades, it appears that the $\mathrm{LPA}_{2}$ receptor signaling can be achieved rapidly and specifically through these $\mathrm{G}$ protein-independent protein-protein interactions. It is of interest to note that these $\mathrm{LPA}_{2}$ receptor-interacting PDZ proteins and LIM-containing proteins possess similar functions in the association with actin, and serve as scaffold or adaptor proteins for the assembly of multi-protein complexes. In particular, TRIP6 and the structurally related LPP contain a class I PDZ-binding motif at their carboxyl-termini, allowing them to interact with PDZ proteins. The PDZ-containing NHERF2, PDZ-RhoGEF, LARG and MAGI-3 mediate LPAinduced activation of RhoA, ERKs and/or AKT, and the LIM-containing TRIP6 regulates LPAinduced ERK activation, adhesion turnover and cell migration in a c-Src-dependent manner. Thus, it is likely that the $\mathrm{LPA}_{2}$ receptor, PDZ proteins and LIM-containing proteins form a supramolecular complex in the microdomain of plasma membrane, and coordinately regulate $\mathrm{LPA}_{2}$ receptor functions in actin remodeling, cell adhesion, migration and/or cell survival. However, several questions remain to be answered, such as the physiological relevance of these protein-protein interactions and the downstream signaling events initiated by these interacting proteins. As the number of the identified LPA receptors is increasing, the LPA signaling pathways are more complex than were previously imagined. To specifically target one particular LPA receptor subtype for therapeutic intervention, it is prerequisite to understand how different interacting proteins regulate the specific signal transduction of each LPA receptor. It is also anticipated that more interacting partners of a particular subtype of LPA receptor will be identified in the near future.

\section{Acknowledgments}

We would like to acknowledge the multiple investigators who made important contributions to the studies of LPA2 mentioned in this article. This work was supported by the National Institute of Health Grant CA100848 (to F.-T. L).

\section{References}

1. Contos JJ, Ishii I, Chun J. Lysophosphatidic acid receptors. Mol Pharmacol 2000;58:1188-96. [PubMed: 11093753]

2. Moolenaar WH, van Meeteren LA, Giepmans BN. The ins and outs of lysophosphatidic acid signaling. Bioessays 2004;26:870-81. [PubMed: 15273989]

3. Moolenaar WH. Bioactive lysophospholipids and their G protein-coupled receptors. Exp Cell Res 1999;253:230-8. [PubMed: 10579925]

4. Moolenaar WH. LPA: a novel lipid mediator with diverse biological actions. Trends Cell Biol 1994;4:213-9. [PubMed: 14731680]

5. Mills GB, Moolenaar WH. The emerging role of lysophosphatidic acid in cancer. Nat Rev Cancer 2003;3:582-91. [PubMed: 12894246]

6. Pasternack SM, von Kugelgen I, Aboud KA, Lee YA, Ruschendorf F, Voss K, Hillmer AM, Molderings GJ, Franz T, Ramirez A, Nurnberg P, Nothen MM, Betz RC. G protein-coupled receptor P2Y5 and its ligand LPA are involved in maintenance of human hair growth. Nat Genet 2008;40:329-34. [PubMed: 18297070]

7. Hecht JH, Weiner JA, Post SR, Chun J. Ventricular zone gene-1 (vzg-1) encodes a lysophosphatidic acid receptor expressed in neurogenic regions of the developing cerebral cortex. J Cell Biol 1996;135:1071-83. [PubMed: 8922387]

8. An S, Bleu T, Hallmark OG, Goetzl EJ. Characterization of a novel subtype of human G proteincoupled receptor for lysophosphatidic acid. J Biol Chem 1998;273:7906-10. [PubMed: 9525886] 
9. Aoki J, Bandoh K, Inoue K. A novel human G-protein-coupled receptor, EDG7, for lysophosphatidic acid with unsaturated fatty-acid moiety. Ann N Y Acad Sci 2000;905:263-6. [PubMed: 10818460]

10. Noguchi K, Ishii S, Shimizu T. Identification of $\mathrm{p} 2 \mathrm{y} 9 / \mathrm{GPR} 23$ as a novel G protein-coupled receptor for lysophosphatidic acid, structurally distant from the Edg family. J Biol Chem 2003;278:25600-6. [PubMed: 12724320]

11. Lee CW, Rivera R, Gardell S, Dubin AE, Chun J. GPR92 as a new G12/13- and Gq-coupled lysophosphatidic acid receptor that increases cAMP, LPA5. J Biol Chem 2006;281:23589-97. [PubMed: 16774927]

12. Tabata K, Baba K, Shiraishi A, Ito M, Fujita N. The orphan GPCR GPR87 was deorphanized and shown to be a lysophosphatidic acid receptor. Biochem Biophys Res Commun 2007;363:861-6. [PubMed: 17905198]

13. Zhang C, Baker DL, Yasuda S, Makarova N, Balazs L, Johnson LR, Marathe GK, McIntyre TM, Xu Y, Prestwich GD, Byun HS, Bittman R, Tigyi G. Lysophosphatidic acid induces neointima formation through PPARgamma activation. J Exp Med 2004;199:763-74. [PubMed: 15007093]

14. McIntyre TM, Pontsler AV, Silva AR, Hilaire A, Xu Y, Hinshaw JC, Zimmerman GA, Hama K, Aoki J, Arai H, Prestwich GD. Identification of an intracellular receptor for lysophosphatidic acid (LPA): LPA is a transcellular PPARgamma agonist. Proc Natl Acad Sci U S A 2003;100:131-6. [PubMed: 12502787]

15. Xu J, Lai YJ, Lin WC, Lin FT. TRIP6 enhances lysophosphatidic acid-induced cell migration by interacting with the lysophosphatidic acid 2 receptor. J Biol Chem 2004;279:10459-68. [PubMed: 14688263]

16. Zhang H, Wang D, Sun H, Hall RA, Yun CC. MAGI-3 regulates LPA-induced activation of Erk and RhoA. Cell Signal 2007;19:261-8. [PubMed: 16904289]

17. Oh YS, Jo NW, Choi JW, Kim HS, Seo SW, Kang KO, Hwang JI, Heo K, Kim SH, Kim YH, Kim IH, Kim JH, Banno Y, Ryu SH, Suh PG. NHERF2 specifically interacts with LPA2 receptor and defines the specificity and efficiency of receptor-mediated phospholipase C-beta3 activation. Mol Cell Biol 2004;24:5069-79. [PubMed: 15143197]

18. Yamada T, Ohoka Y, Kogo M, Inagaki S. Physical and functional interactions of the lysophosphatidic acid receptors with PDZ domain-containing Rho guanine nucleotide exchange factors (RhoGEFs). J Biol Chem 2005;280:19358-63. [PubMed: 15755723]

19. Lin FT, Lai YJ, Makarova N, Tigyi G, Lin WC. The Lysophosphatidic Acid 2 Receptor Mediates Down-regulation of Siva-1 to Promote Cell Survival. J Biol Chem 2007;282:37759-69. [PubMed: 17965021]

20. Li C, Dandridge KS, Di A, Marrs KL, Harris EL, Roy K, Jackson JS, Makarova NV, Fujiwara Y, Farrar PL, Nelson DJ, Tigyi GJ, Naren AP. Lysophosphatidic acid inhibits cholera toxin-induced secretory diarrhea through CFTR-dependent protein interactions. J Exp Med 2005;202:975-86. [PubMed: 16203867]

21. Yun CC, Sun H, Wang D, Rusovici R, Castleberry A, Hall RA, Shim H. LPA2 receptor mediates mitogenic signals in human colon cancer cells. Am J Physiol Cell Physiol 2005;289:C2-11. [PubMed: 15728708]

22. Contos JJ, Ishii I, Fukushima N, Kingsbury MA, Ye X, Kawamura S, Brown JH, Chun J. Characterization of lpa(2) (Edg4) and lpa(1)/lpa(2) (Edg2/Edg4) lysophosphatidic acid receptor knockout mice: signaling deficits without obvious phenotypic abnormality attributable to lpa(2). Mol Cell Biol 2002;22:6921-9. [PubMed: 12215548]

23. Shida D, Watanabe T, Aoki J, Hama K, Kitayama J, Sonoda H, Kishi Y, Yamaguchi H, Sasaki S, Sako A, Konishi T, Arai H, Nagawa H. Aberrant expression of lysophosphatidic acid (LPA) receptors in human colorectal cancer. Lab Invest 2004;84:1352-62. [PubMed: 15220934]

24. Kitayama J, Shida D, Sako A, Ishikawa M, Hama K, Aoki J, Arai H, Nagawa H. Over-expression of lysophosphatidic acid receptor-2 in human invasive ductal carcinoma. Breast Cancer Res 2004;6:R640-6. [PubMed: 15535846]

25. Fang X, Gaudette D, Furui T, Mao M, Estrella V, Eder A, Pustilnik T, Sasagawa T, Lapushin R, Yu S, Jaffe RB, Wiener JR, Erickson JR, Mills GB. Lysophospholipid growth factors in the initiation, progression, metastases, and management of ovarian cancer. Ann N Y Acad Sci 2000;905:188-208. [PubMed: 10818454] 
26. Schulte KM, Beyer A, Kohrer K, Oberhauser S, Roher HD. Lysophosphatidic acid, a novel lipid growth factor for human thyroid cells: over-expression of the high-affinity receptor edg 4 in differentiated thyroid cancer. Int J Cancer 2001;92:249-56. [PubMed: 11291053]

27. Umezu-Goto M, Kishi Y, Taira A, Hama K, Dohmae N, Takio K, Yamori T, Mills GB, Inoue K, Aoki J, Arai H. Autotaxin has lysophospholipase D activity leading to tumor cell growth and motility by lysophosphatidic acid production. J Cell Biol 2002;158:227-33. [PubMed: 12119361]

28. Boucharaba A, Serre CM, Gres S, Saulnier-Blache JS, Bordet JC, Guglielmi J, Clezardin P, Peyruchaud O. Platelet-derived lysophosphatidic acid supports the progression of osteolytic bone metastases in breast cancer. J Clin Invest 2004;114:1714-25. [PubMed: 15599396]

29. Hur EM, Kim KT. G protein-coupled receptor signalling and cross-talk: achieving rapidity and specificity. Cell Signal 2002;14:397-405. [PubMed: 11882384]

30. Maudsley S, Martin B, Luttrell LM. The origins of diversity and specificity in g protein-coupled receptor signaling. J Pharmacol Exp Ther 2005;314:485-94. [PubMed: 15805429]

31. Cho KO, Hunt CA, Kennedy MB. The rat brain postsynaptic density fraction contains a homolog of the Drosophila discs-large tumor suppressor protein. Neuron 1992;9:929-42. [PubMed: 1419001]

32. Kim E, Niethammer M, Rothschild A, Jan YN, Sheng M. Clustering of Shaker-type K+ channels by interaction with a family of membrane-associated guanylate kinases. Nature 1995;378:85-8. [PubMed: 7477295]

33. Fanning AS, Anderson JM. Protein-protein interactions: PDZ domain networks. Curr Biol 1996;6:1385-8. [PubMed: 8939589]

34. Kornau HC, Schenker LT, Kennedy MB, Seeburg PH. Domain interaction between NMDA receptor subunits and the postsynaptic density protein PSD-95. Science 1995;269:1737-40. [PubMed: 7569905]

35. Sato T, Irie S, Kitada S, Reed JC. FAP-1: a protein tyrosine phosphatase that associates with Fas. Science 1995;268:411-5. [PubMed: 7536343]

36. Sheng M, Sala C. PDZ domains and the organization of supramolecular complexes. Annu Rev Neurosci 2001;24:1-29. [PubMed: 11283303]

37. Weinman EJ, Shenolikar S. Regulation of the renal brush border membrane $\mathrm{Na}(+)-\mathrm{H}+$ exchanger. Annu Rev Physiol 1993;55:289-304. [PubMed: 8385434]

38. Shenolikar S, Weinman EJ. NHERF: targeting and trafficking membrane proteins. Am J Physiol Renal Physiol 2001;280:F389-95. [PubMed: 11181400]

39. Weinman EJ, Shenolikar S. The Na-H exchanger regulatory factor. Exp Nephrol 1997;5:449-52. [PubMed: 9438172]

40. Kleizen B, Braakman I, de Jonge HR. Regulated trafficking of the CFTR chloride channel. Eur J Cell Biol 2000;79:544-56. [PubMed: 11001491]

41. Weinman EJ, Hall RA, Friedman PA, Liu-Chen LY, Shenolikar S. The association of NHERF adaptor proteins with g protein-coupled receptors and receptor tyrosine kinases. Annu Rev Physiol 2006;68:491-505. [PubMed: 16460281]

42. Hall RA, Ostedgaard LS, Premont RT, Blitzer JT, Rahman N, Welsh MJ, Lefkowitz RJ. A C-terminal motif found in the beta2-adrenergic receptor, $\mathrm{P} 2 \mathrm{Y} 1$ receptor and cystic fibrosis transmembrane conductance regulator determines binding to the $\mathrm{Na}+\mathrm{H}+$ exchanger regulatory factor family of PDZ proteins. Proc Natl Acad Sci U S A 1998;95:8496-501. [PubMed: 9671706]

43. Hall RA, Premont RT, Chow CW, Blitzer JT, Pitcher JA, Claing A, Stoffel RH, Barak LS, Shenolikar S, Weinman EJ, Grinstein S, Lefkowitz RJ. The beta2-adrenergic receptor interacts with the $\mathrm{Na}+\mathrm{H}$ +-exchanger regulatory factor to control $\mathrm{Na}+\mathrm{H}+$ exchange. Nature 1998;392:626-30. [PubMed: 9560162]

44. Shenolikar S, Minkoff CM, Steplock DA, Evangelista C, Liu M, Weinman EJ. N-terminal PDZ domain is required for NHERF dimerization. FEBS Lett 2001;489:233-6. [PubMed: 11165256]

45. Lau AG, Hall RA. Oligomerization of NHERF-1 and NHERF-2 PDZ domains: differential regulation by association with receptor carboxyl-termini and by phosphorylation. Biochemistry 2001;40:857280. [PubMed: 11456497]

46. Guggino SE. Gates of Janus: cystic fibrosis and diarrhea. Trends Microbiol 1994;2:91-4. [PubMed: 7512420] 
47. Vazquez-Prado J, Basile J, Gutkind JS. Modular architecture and novel protein-protein interactions regulating the RGS-containing Rho guanine nucleotide exchange factors. Methods Enzymol 2004;390:259-85. [PubMed: 15488183]

48. Bian D, Mahanivong C, Yu J, Frisch SM, Pan ZK, Ye RD, Huang S. The G12/13-RhoA signaling pathway contributes to efficient lysophosphatidic acid-stimulated cell migration. Oncogene 2006;25:2234-44. [PubMed: 16301993]

49. Dhanasekaran DN. Transducing the signals: a G protein takes a new identity. Sci STKE 2006;2006:pe31. [PubMed: 16896192]

50. Gohla A, Harhammer R, Schultz G. The G-protein G13 but not G12 mediates signaling from lysophosphatidic acid receptor via epidermal growth factor receptor to Rho. J Biol Chem 1998;273:4653-9. [PubMed: 9468525]

51. Dobrosotskaya I, Guy RK, James GL. MAGI-1, a membrane-associated guanylate kinase with a unique arrangement of protein-protein interaction domains. J Biol Chem 1997;272:31589-97. [PubMed: 9395497]

52. Wu Y, Dowbenko D, Spencer S, Laura R, Lee J, Gu Q, Lasky LA. Interaction of the tumor suppressor PTEN/MMAC with a PDZ domain of MAGI3, a novel membrane-associated guanylate kinase. J Biol Chem 2000;275:21477-85. [PubMed: 10748157]

53. Adamsky K, Arnold K, Sabanay H, Peles E. Junctional protein MAGI-3 interacts with receptor tyrosine phosphatase beta (RPTP beta) and tyrosinephosphorylated proteins. J Cell Sci 2003;116:1279-89. [PubMed: 12615970]

54. Franklin JL, Yoshiura K, Dempsey PJ, Bogatcheva G, Jeyakumar L, Meise KS, Pearsall RS, Threadgill D, Coffey RJ. Identification of MAGI-3 as a transforming growth factor-alpha tail binding protein. Exp Cell Res 2005;303:457-70. [PubMed: 15652357]

55. He J, Bellini M, Inuzuka H, Xu J, Xiong Y, Yang X, Castleberry AM, Hall RA. Proteomic analysis of beta1-adrenergic receptor interactions with PDZ scaffold proteins. J Biol Chem 2006;281:28207. [PubMed: 16316992]

56. Yao R, Natsume Y, Noda T. MAGI-3 is involved in the regulation of the JNK signaling pathway as a scaffold protein for frizzled and Ltap. Oncogene 2004;23:6023-30. [PubMed: 15195140]

57. Bach I. The LIM domain: regulation by association. Mech Dev 2000;91:5-17. [PubMed: 10704826]

58. Prasad KV, Ao Z, Yoon Y, Wu MX, Rizk M, Jacquot S, Schlossman SF. CD27, a member of the tumor necrosis factor receptor family, induces apoptosis and binds to Siva, a proapoptotic protein. Proc Natl Acad Sci U S A 1997;94:6346-51. [PubMed: 9177220]

59. Wang Y, Gilmore TD. Zyxin and paxillin proteins: focal adhesion plaque LIM domain proteins go nuclear. Biochim Biophys Acta 2003;1593:115-20. [PubMed: 12581855]

60. Zhao MK, Wang Y, Murphy K, Yi J, Beckerle MC, Gilmore TD. LIM domain-containing protein trip6 can act as a coactivator for the v- Rel transcription factor. Gene Expr 1999;8:207-17. [PubMed: 10794523]

61. Kassel O, Schneider S, Heilbock C, Litfin M, Gottlicher M, Herrlich P. A nuclear isoform of the focal adhesion LIM-domain protein Trip6 integrates activating and repressing signals at AP-1- and NFkappaB-regulated promoters. Genes Dev 2004;18:2518-28. [PubMed: 15489293]

62. Yi J, Kloeker S, Jensen CC, Bockholt S, Honda H, Hirai H, Beckerle MC. Members of the Zyxin family of LIM proteins interact with members of the p130Cas family of signal transducers. J Biol Chem 2002;277:9580-9. [PubMed: 11782456]

63. Wang Y, Gilmore TD. LIM domain protein Trip6 has a conserved nuclear export signal, nuclear targeting sequences, and multiple transactivation domains. Biochim Biophys Acta 2001;1538:26072. [PubMed: 11336797]

64. Lai YJ, Chen CS, Lin WC, Lin FT. c-Src-mediated phosphorylation of TRIP6 regulates its function in lysophosphatidic acid-induced cell migration. Mol Cell Biol 2005;25:5859-68. [PubMed: 15988003]

65. Murthy KK, Clark K, Fortin Y, Shen SH, Banville D. ZRP-1, a zyxin-related protein, interacts with the second PDZ domain of the cytosolic protein tyrosine phosphatase hPTP1E. J Biol Chem 1999;274:20679-87. [PubMed: 10400701]

66. Lai YJ, Lin WC, Lin FT. PTPL1/FAP-1 Negatively Regulates TRIP6 Function in Lysophosphatidic Acid-induced Cell Migration. J Biol Chem 2007;282:24381-7. [PubMed: 17591779] 
67. Ye X, Ishii I, Kingsbury MA, Chun J. Lysophosphatidic acid as a novel cell survival/apoptotic factor. Biochim Biophys Acta 2002;1585:108-13. [PubMed: 12531543]

68. Radeff-Huang J, Seasholtz TM, Matteo RG, Brown JH. G protein mediated signaling pathways in lysophospholipid induced cell proliferation and survival. J Cell Biochem 2004;92:949-66. [PubMed: 15258918]

69. Goetzl EJ, Lee H, Dolezalova H, Kalli KR, Conover CA, Hu YL, Azuma T, Stossel TP, Karliner JS, Jaffe RB. Mechanisms of lysolipid phosphate effects on cellular survival and proliferation. Ann N Y Acad Sci 2000;905:177-87. [PubMed: 10818453]

70. Hu X, Haney N, Kropp D, Kabore AF, Johnston JB, Gibson SB. Lysophosphatidic acid (LPA) protects primary chronic lymphocytic leukemia cells from apoptosis through LPA receptor activation of the anti-apoptotic protein AKT/PKB. J Biol Chem 2005;280:9498-508. [PubMed: 15618220]

71. Virag T, Elrod DB, Liliom K, Sardar VM, Parrill AL, Yokoyama K, Durgam G, Deng W, Miller DD, Tigyi G. Fatty alcohol phosphates are subtype-selective agonists and antagonists of lysophosphatidic acid receptors. Mol Pharmacol 2003;63:1032-42. [PubMed: 12695531]

72. Deng W, Shuyu E, Tsukahara R, Valentine WJ, Durgam G, Gududuru V, Balazs L, Manickam V, Arsura M, VanMiddlesworth L, Johnson LR, Parrill AL, Miller DD, Tigyi G. The lysophosphatidic acid type 2 receptor is required for protection against radiation-induced intestinal injury. Gastroenterology 2007;132:1834-51. [PubMed: 17484878]

73. Fortin A, MacLaurin JG, Arbour N, Cregan SP, Kushwaha N, Callaghan SM, Park DS, Albert PR, Slack RS. The proapoptotic gene SIVA is a direct transcriptional target for the tumor suppressors p53 and E2F1. J Biol Chem 2004;279:28706-14. [PubMed: 15105421]

74. Py B, Slomianny C, Auberger P, Petit PX, Benichou S. Siva-1 and an alternative splice form lacking the death domain, Siva-2, similarly induce apoptosis in T lymphocytes via a caspase-dependent mitochondrial pathway. J Immunol 2004;172:4008-17. [PubMed: 15034012]

75. Gudi R, Barkinge J, Hawkins S, Chu F, Manicassamy S, Sun Z, Duke-Cohan JS, Prasad KV. Siva-1 negatively regulates NF-kappaB activity: effect on T-cell receptor-mediated activation-induced cell death (AICD). Oncogene 2006;25:3458-62. [PubMed: 16491128]

76. Xue L, Chu F, Cheng Y, Sun X, Borthakur A, Ramarao M, Pandey P, Wu M, Schlossman SF, Prasad KV. Siva-1 binds to and inhibits BCL-X(L)-mediated protection against UV radiation-induced apoptosis. Proc Natl Acad Sci U S A 2002;99:6925-30. [PubMed: 12011449]

77. Wojcikiewicz RJ. Regulated ubiquitination of proteins in GPCR-initiated signaling pathways. Trends Pharmacol Sci 2004;25:35-41. [PubMed: 14723977] 
Table I

Proteins interacting with the carboxyl-terminal tail of the $\mathrm{LPA}_{2}$ receptor

\begin{tabular}{llll}
\hline Binding motif & Interacting protein & Functional significance & References \\
\hline $\begin{array}{l}\text { PDZ-binding motif } \\
\text { (distal end) }\end{array}$ & NHERF2 & Activation of PLC- $\beta 3$ signaling pathways & {$[17]$} \\
& & Activation of AKT and ERKs & {$[21]$} \\
& & Linking LPA ${ }_{2}$ with CFTR to inhibit CFTR activity & {$[20]$} \\
& PDZ-RhoGEF & RhoA activation & {$[18]$} \\
& MARG & & {$[16]$} \\
$\begin{array}{l}\text { Zinc finger-binding } \\
\text { motif } \\
\text { (proximal region) }\end{array}$ & Activation of RhoA and ERKs & {$[15,64,66]$} \\
& TRIP6 & Regulation of cell migration through & c-Src/PTPL1-dependent phosphorylation \\
& & and dephosphorylation & ERK activation \\
& & Interactions mediate down-regulation of & {$[19]$} \\
\hline
\end{tabular}

